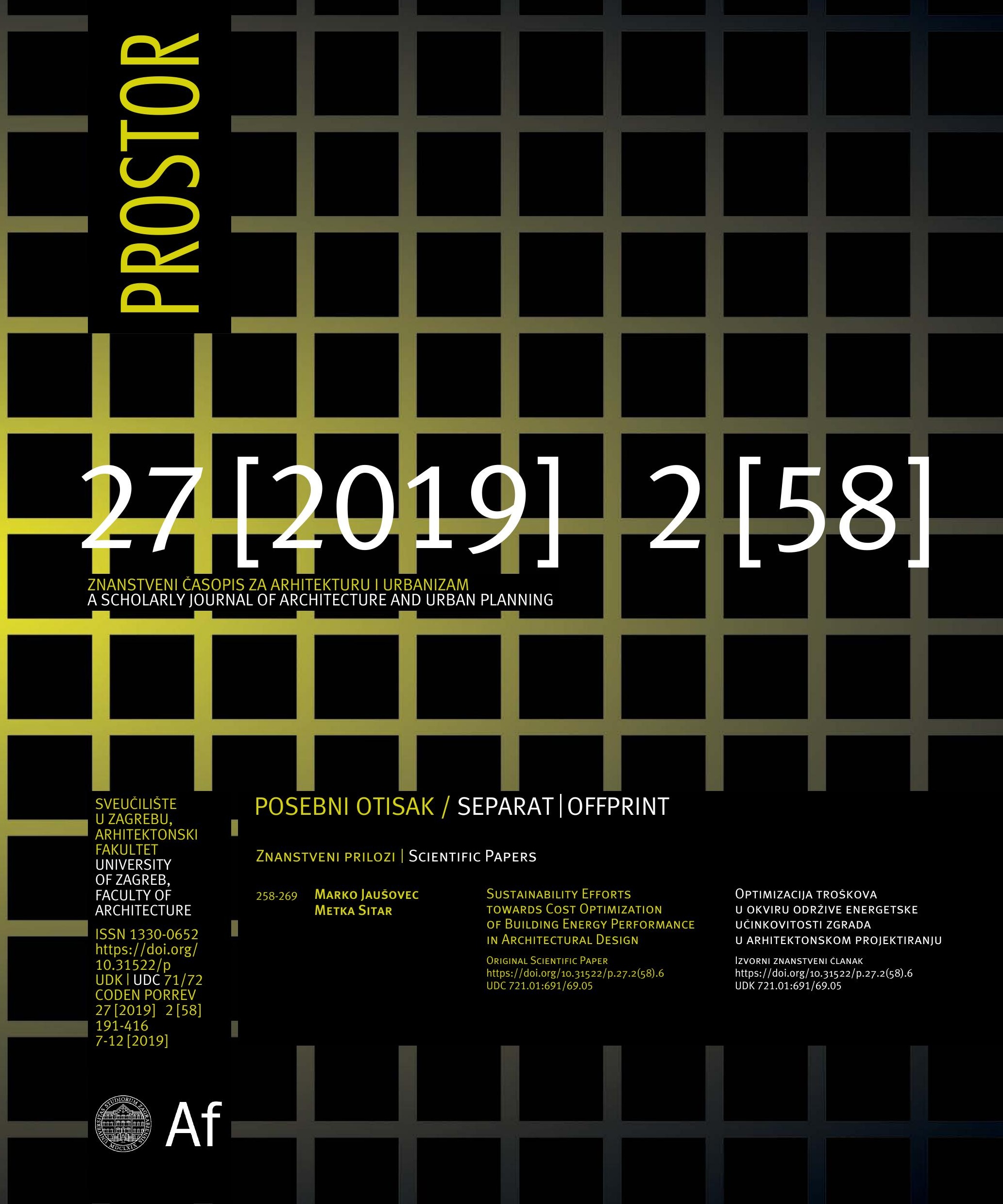




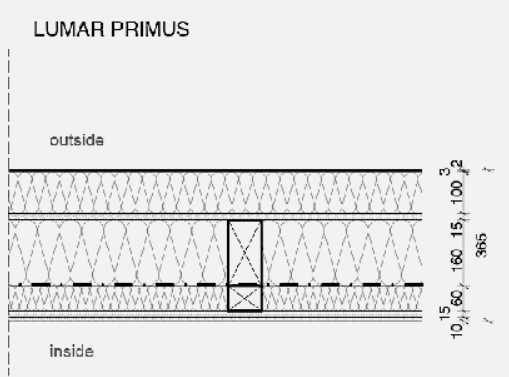

outside

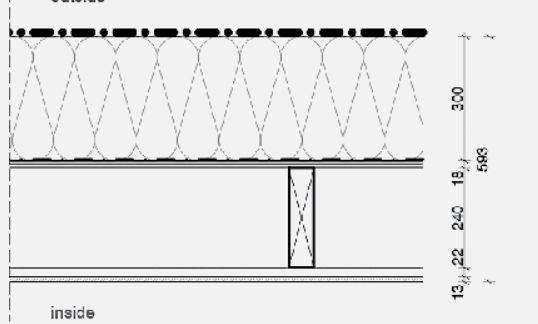

WALL

materlal
Plaster Thin

|Paster tenturcerner|

Mineral insulation wc

Plasterboarc

Colluluse irisulaturi \& (Larrun aced

yivecte sluds 180;20)

vapour barrier

Mineral wool insulazion \&

(turnter sluds aniso)

Plastertbuerd

Plasterboard

Wall thickness ( $(\mathrm{mm})$
Unval-value (W/m2K)

ROOF

material

Polyathylene waterpronfing membrana

Mincrnl inclined insuldation

bilumicri veyour banter

OSE panel

I aminatad spnuse heam

timber under comstniction

Plasterbcard

Roof thlekness

$\mathrm{U}_{\mathrm{mar}}$ Value (W/m2K)
ECOLAR

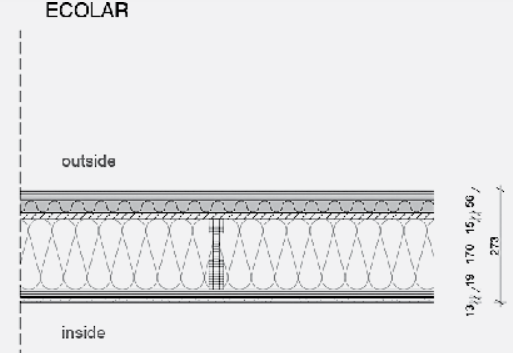

outside

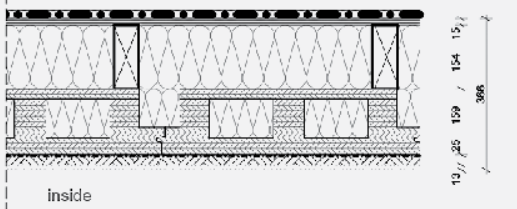

WALL

material
Luciou systern

MDГ $\Gamma$ board

Thermo-Hemp WCG thetwa

Lgnotrond U'PSIt t b'1 $/ 0$ elomonts)

OSB panel

Plasterhnars

Wall thickness

Unail-value (W/m2K)

thickness (mm)

56
15

$1 / 0$

19

12.5
273

0,10

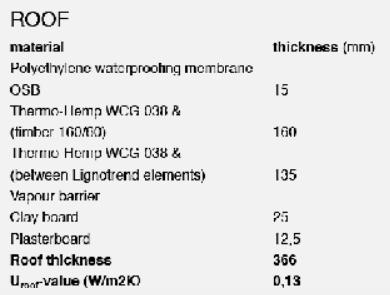

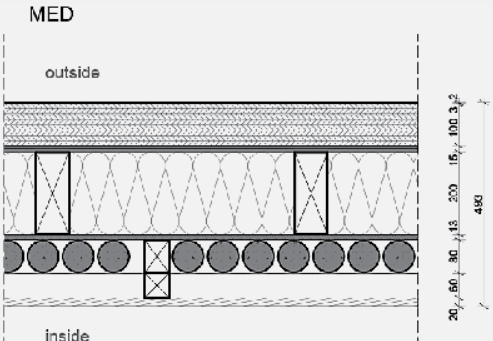

outside

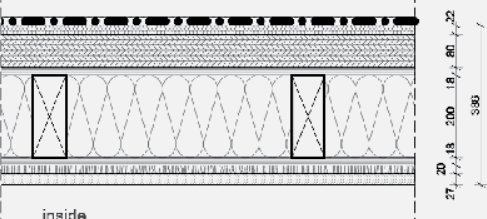

WALL

materlal
Plaster Thin

I'lasler rerlluctenter|

ravatherm Flus

OSD

200n

Plasterícuard periel

Alu pipes (rounc) + wet send

Timber baftens 6atan

Suld ivoud peniol

Wall thicknegs

$\mathrm{U}_{\text {wurlrvalue }}(\mathrm{W} / \mathrm{m} 2 \mathrm{~K})$

leknose (mm)

200min

12.5

(1)

493

0,14

ROOF

materlal

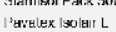

Pavathem Plus

OSD

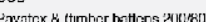

us

Gypsum Fitrotonard (Farmacal)

Roof thickness

U.

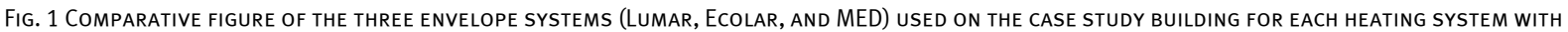
MAIN PROPERTIES FOR THIS RESEARCH

SL. 1. USPOREDNI PRIKAZ TRI SUSTAVA OMOTAČA (LUMAR, ECOLAR I MED) ZA SVAKI SUSTAV GRIJANJA S GLAVNIM SVOJSTVIMA 


\section{Marko Jaušovec, Metka Sitar}

UNIVERSITY OF MARIBOR

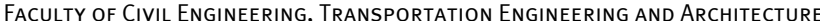
SLOVENIA - 2000 MARIBOR, SMETANOVA ULICA 17

marko.jausovec@um.si

metka.sitar@um.si

ORIGINAL SCIENTIFIC PAPER

https://doi.org/10.31522/p.27.2(58).6

UDC 721.01:691/69.05

Technical Sciences / Architecture and Urban Planning

2.01.03. - ArChitectural Structures, Building Physics, MATERIALS AND BUILDING TECHNOLOGY

Article Received / ACCEPted: 15. 9. 2019. / 16. 12. 2019.
SVEUĊILIŠTE U MARIBORU

FAKULTET ZA GRADEVINARSTVO, SAOBRACAINI INŻENJERING I ARHITEKTURI

SLOVENIJA - 2000 MARIBOR, SMETANOVA ULICA 17

marko.jausovec@um.si

metka.sitar@um.si

IZVORNI ZNANSTVENI CLANAK

https://doi.org/10.31522/p.27.2(58).6

UDK 721.01:691/69.05

TEHNIČKE ZNANOSTI / ARHITEKTURA I URBANIZAM

2.01.03. - ARHITEKTONSKE KONSTRUKCIJE, FIZIKA ZGRADE, MATERIJALI I TEHNOLOGIJA GRADENJA

ČLANAK PRIMLJEN / PRIHVACEN: 15. 9. 2019. / 16. 12. 2019.

\title{
SUSTAINABILITY EFFORTS TOWARDS COST OPTIMIZATION of Building Energy Performance in Architectural Design
}

\author{
OPTIMIZACIJA TROŠKOVA U OKVIRU \\ ODRŽIVE ENERGETSKE UČINKOVITOSTI ZGRADA \\ U ARHITEKTONSKOM PROJEKTIRANJU
}

BIM

COST OPTIMIZATION

ENERGY EFFICIENCY

HEATING SYSTEM

LCC ASSESSMENT

Regarding the efforts towards sustainable architectural design, the issue of energy efficiency is in the focus of stakeholders' decision making on the cost optimal investment in building sector. The paper summarizes the findings on cost optimisation by introducing the BIM-supported LCC assessment method used for different heating systems as a tool applicable in the early phase of the architectural design process.

\author{
BIM \\ OPTIMIZACIJA TROŠKOVA \\ ENERGETSKA UČINKOVITOST \\ SUSTAV GRIJANJA \\ LCC PROCJENA
}

U okviru održivog arhitektonskog projektiranja, problematika energetske učinkovitosti u središtu je interesa svih sudionika u procesu njihovog odlučivanja o optimalnom investiranju u građevinskom sektoru. Ovaj rad predstavlja rezultate studije o procjeni troškova żivotnog ciklusa [LCC assessment] na temelju informacijskog modeliranja građevine [BIM] koja je dokazala da je metoda primjenjiva u ranim fazama procesa projektiranja. 


\section{INTRODUCTION}

\section{UVOD}

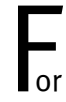

decades, the society has been increasingly concerned about the quality of the environment, especially about the damages caused by built environment. Building industry has a strong impact on society's sustainability as it consumes a significant amount of raw materials. ${ }^{1}$

In the $\mathrm{EU}$, the building sector alone accounts for $38 \%$ of carbon dioxide $\left[\mathrm{CO}_{2}\right]$ emissions and is responsible for $40 \%$ of the energy consumption. ${ }^{2}$ Similarly, in Slovenia the energy consumption for heating in buildings accounts for approximately $25 \%$ of total primary energy. An essential share is consumed by single-family houses, which represent $75 \%$ of residential floor area, and $55 \%$ of the entire building sector area. ${ }^{3}$ In past decades, the EU introduced a range of documents to reduce energy consumption and energy emissions, among them, as essential, the Energy Performance of Buildings Directives 2002/91/EC [EPBD] in 2002. Slovenia harmonized the EU documents on energy efficiency by adopting The Regulations for the Efficient Use of Energy in Buildings in 2010 that include The Technical Guidance, prescribing minimal standards on design, construction, and maintenance of sustainable buildings. 4 Within today's efforts directed towards the design of comfortable and quality indoor spaces with as little energy consumption as possible ${ }^{5}$, there is a need to understand the operational processes incorporating the effectiveness of heating systems. ${ }^{6}$

\section{LITERATURE OVERVIEW}

\section{PREGLED LITERATURE}

The correlation between household energy consumption and a variety of socio-economic parameters has been addressed in scientific literature worldwide. Most of them consider cost and thermal characteristics of buildings as primary variables. Sandvall et al. ${ }^{7}$ conducted research on cost efficiency of urban heating strategies considering three economic indicators of the economic sustainability assessment, as, (i) capital costs, (ii) total annualized costs, and, (iii) levelized costs. In recent studies, the researchers Xydis and Milan et al. used linear programming on the development of low energy building optimization approaches. ${ }^{8,9}$ Similarly, the tool ORES ${ }^{10}$ was introduced as a linear decision support in order to determine the optimum investment and operating choices for residential energy systems. However, most of the research has been limited only on the yearly energy costs or implemented genetic algorithms and complex problems that were greatly non-linear. ${ }^{11,12}$ Further, Martinopoulos et al. ${ }^{13}$ introduced contemporary heating systems enabling the analysis of operational costs for households on the basis of their seasonal efficiency and fuel costs.

Over the last 10 years, according to Langdon, the Life Cycle Costing (LCC) is considered as the major component in environmental sustainability assessment in construction, offering a tool for economic evaluation of sustainability alternatives with different capital costs, operational costs, and resource utilization. Additionally, it contains the methods to assess the cost advantages of integrating more sustainable alternatives into built property. ${ }^{14}$ The LCC represents one of the modifications in project cost management in the evaluation of financial feasibility including the value of different technological systems. ${ }^{15}$ In recent

\footnotetext{
1 Yin et al., 2018: 613-620

2 Energy - European Commission, 2018

3 ZAVRL, GJERKEŠ, TOMŠIČ, 2012: 163

4 GLUŠIČ, 2019

5 BRADIĆ, VERŠIĆ, 2018: 257

6 MARTINOPOULOS, PAPAKOStAS, PAPAdopoulos, 2018: 687-699

7 Sandvall, Ahlgre, Ekvall, 2017: 212-223

8 XYDIS, 2013: 198-210

9 Milan, Bojesen, Nielsen, 2012: 118-127

10 LAUINGER et al., 2016: 24-37

11 Peippo, Lund, Vartiainen, 1999: 189-205

12 WANG, ZMEUREANU, RiVARD, 2005: 1512-1525

13 Martinopoulos, PAPAKostas, Papadopoulos, 2018 : 687-699

14 Civil Engineering Division, Ministry of Transport Public Works \& Water Management, 2007: 3-4

15 KARAN, IRIZARRY, 2015: 1-12

16 LEE, KIM, NA, 2015: 67-74
} 
studies, there are efforts to include the energy costs in operational phase; however, they did not holistically combine the LCC evaluation when assessing alternative building systems. In view of operational costs, the relevant parameters have been also introduced by a number of researchers. ${ }^{16,17,18,19,20,21}$

Being aware of certain limits of the LCC method, the use of Building Information Modelling (BIM) tools emerged as a fresh trend in the construction industry to enhance the building assessment methods towards sustainable architectural design. Referring to the LCC effectiveness in terms of sustainability, $\mathrm{Du}$ et al. claim that the holistic approach to project results offers a greater value as essential for the decision, whether or not a system would be appropriate. ${ }^{22}$ When incorporating the BIM into the methodologies for evaluating buildings' environmental impact and energy consumption, the higher levels of urban environment sustainability could be achieved. ${ }^{23}$ According to Deshpande et al., the BIM repository that efficiently manages data and knowledge during the construction delivery phase would improve the delivery of sustainable building value. ${ }^{24}$ Further, Uygunog et al. estimate that many cost-optimal methodology studies are performed through manual processes, which may not result in a high level of precision. ${ }^{21}$ In contrast, according to Basbagill et al., the automated process could enhance the accuracy of the results when searching for the minimum total cost of a building. ${ }^{25}$ An additional aspect regarding the BIM used as a supporting tool provides the Building Energy Model (BEM) characterized by a complete and automatic BIM workflow. ${ }^{26}$ According to Motawaa and Carterb, the BIM energy analysis implemented already in the design phase could improve the post-occupancy evaluation process intended to meet the industry requirements for sustainable buildings. ${ }^{27}$ The discussion on ad-

\footnotetext{
17 Hasan, Vuolle, Sirén, 2008: 2022-2034

18 LECKNER, ZMEUREANU, 2011: 232-241

19 MATIC et al., 2015: 74-81

20 UYGUnoĞLU, KeÇEBAŞ, 2011: 2077-2085

21 FERrara et al., 2016: 109-127

22 Du et al., 2016: 30-43

23 SANTOS, COSTA, 2016: 1

24 Deshrande, Azhar, Amireddy, 2014: 113-122

25 Basbagill, Flager, LePECH, 2014: 136-150

26 Graphisoft.com, 2019

27 Motawa, Carter, 2013: 419-428

28 REN, LI, 2017: 51-62

29 LOVE et al., 2015: 26-35

30 GRILO, JARDIM-GonCALVES, 2011: 107-114

31 SANtos et al., 2019: 127-149; SHIN, CHO, 2015: 1-14; SANTOS et al., 2019: 127-149; NWODO, ANUMBA, ASADI, 2017

32 Sandvall, Ahlgren, EkVall, 2017: 212-223; SAHA, 2011: 1913-1919; LAUINGER et al., 2016: 24-37; XYDIS, 2013: 198-210
}

vantages of the BIM based LCC assessment are explained in several recent studies. ${ }^{28,29}$ Among them, Grilo and Jardim-Goncalves pointed out the engineering view based on the perception that the BIM is improving the LCC by providing benefits for management frameworks, tools, standards and assessment methods over the whole project lifecycle. ${ }^{30}$

\section{LIMITS AND AIMS \\ OGRANIČENJA I CILJEVI}

In Slovenia, almost 90\% of residential sector is privately owned that's why the total operational costs and the value of the investment are of significant importance in the eyes of investors and users. Consequently, an essential share of energy consumption is spent for space heating of households. Due to the increased focus on economic performance of construction projects, by using the LCC, most of the projects' elements could be included in the assessment of buildings energy performance. However, in the literature on the BIMbased LCC analyses, which explore the advantages and propose a range of integration frameworks ${ }^{31}$, it could be summarised that a more empirical approach, as for example introducing the Legep database is desirable. The fact is that the perceived complexity and time consuming nature of calculations like linear programming could lead to non-comprehensive BIM-LCC evaluations of economic feasibility using only parts of entire costs, mostly the energy related ones. ${ }^{32}$ Therefore, a study on the simultaneous use of the BIM supported LCC method for the assessment of different heating systems in the relation to envelopes systems is completely missing. Lastly, conducted LCC analyses were limited on a specific lifetime period of 30,50 , or 80 years, but there was no cost-optimal assessment of the cost's evolution during a specified lifetime period to be found.

Following the theoretical background and the limits identified this paper aims to

(i) conduct a comprehensive BIM supported LCC assessment of three alternative heating systems as gas, pellet and heat pump in relation to three advanced prefabricated envelopes systems designed for a single-family house as a case study building with alternatives of system envelopes as a reference-, a high-tech and a low-tech envelope type by using the adapted Extended Comparative Evaluation Model Framework [ECEMF],

(ii) use the BIM [ArchiCAD] and LCC [Legep] tools to demonstrate the semi-automatic BIM supported LCC assessment, and

(iii) evaluate the cost optimal heating system for energy-efficient prefabricated single-family house over the life time period of 50 years.

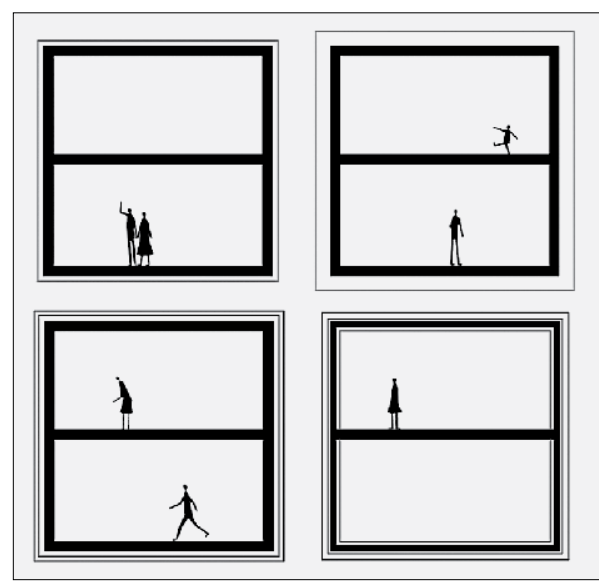

FIG. 2 SUSTAINABILITY EFFORTS TOWARDS COST OPTIMIZATION OF BUILDING ENERGY PERFORMANCE IN ARCHITECTURAL DESIGN

SL. 2. NASTOJANJA PREMA POSTIZANJU OPTIMIZACIJE TROŠKOVA U POGLEDU ENERGETSKE UCINKOVITOSTI ZGRADE U ARHITEKTONSKOM PROJEKTIRANJU 


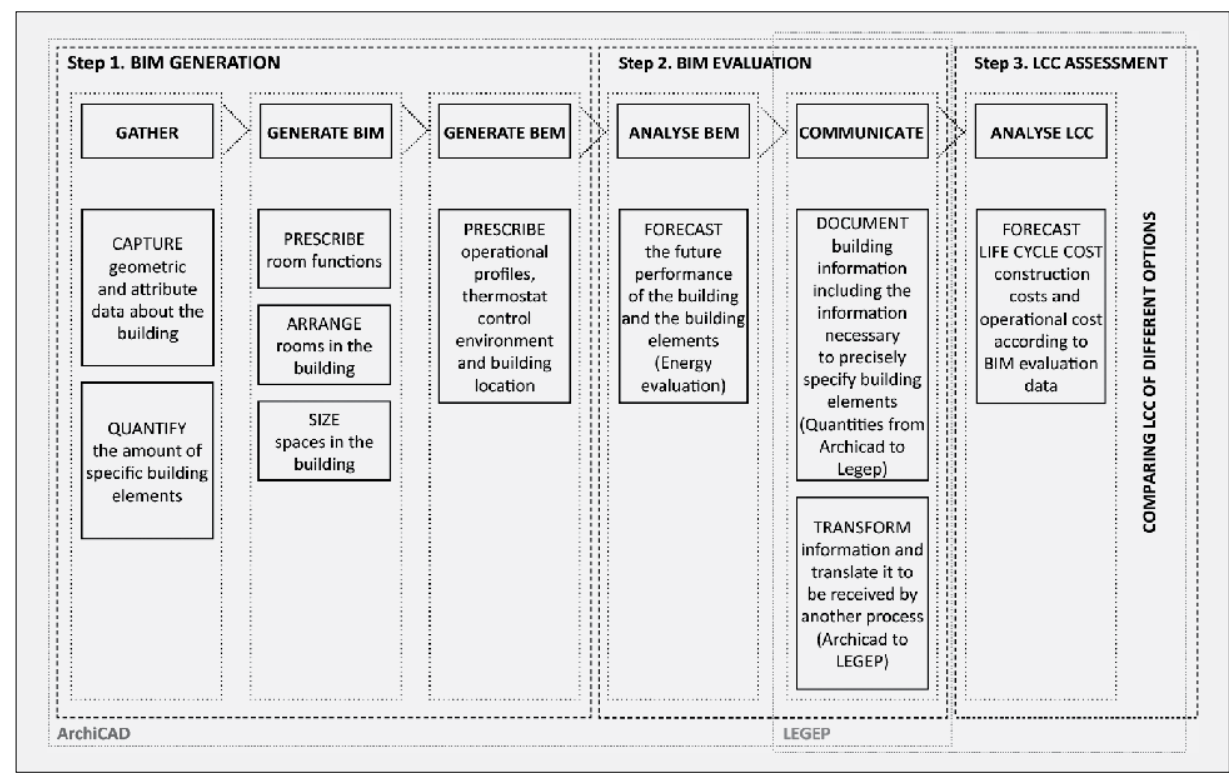

FIG. 3 THE ADAPTED ECEMF USED IN THIS STUDY. THE ADAPTED COMPARATIVE EVALUATION FRAMEWORK MODEL IS BASED ON THREE MAIN STEPS OF EVALUATION: STEP 1. THE BIM GENERATION, GATHERING AND GENERATING THE BUILDING DATA, STEP 2. THE BIM EVALUATION, ANALYSING BEM AND COMMUNICATING THE RESULTS BETWEEN TOOLS USED, AND STEP 3. THE LCC ASSESSMENT, ANALYSING THE LCC.

SL. 3. PRILAGODENI ECEMF MODEL KORIŚTEN U OVOJ STUDIII. PRILAGODENI MODEL KOMPARATIVNE EVALUACIJE UTEMELJEN JE U 3 TRI GLAVNE FAZE PROCJENJIVANJA: FAZA 1. BIM GENERIRANJE, PRIKUPLJANJE I GENERIRANJE PODATAKA O GRADEVINI. FAZA 2. BIM EVALUACIIA, BEM ANALIZA I USPOREDIVANIE REZULTATA IZMEĐU KORIŚTENIH ALATA. FAZA 3. LCC PROCJENA, LCC ANALIZA.

Fig. 4 Net present Value [NPV] equation SL. 4. JEDNADŻBA NETO SADAŚNJE VRIJEDNOSTI [NPV]

$$
\mathrm{C}_{0}=\sum_{t=0}^{T} \frac{C_{t}}{(1+i)^{t}} \quad \begin{aligned}
& \text { Co: cash value } \\
& \text { Ct: sum of payments } \\
& \text { t: current time } \\
& \begin{array}{l}
\mathrm{T}: \text { viewing horizon } \\
\text { i: calculation interest rate }
\end{array}
\end{aligned}
$$

\section{METHODS}

\section{METODE}

In the following subchapters, the methodology based on the LCC for the life-span of 50 years combining BIM with the LCC assessment is introduced with the aim of exploring the energy costs relationship between three different heating systems calculated on the alternatives of three different prefabricated envelopes.

- Extended comparative evaluation model framework [ECEMF] - The ECEMF ${ }^{33}$ is a comparative evaluation model framework usable by different stakeholders when adopting the decision on the most optimal system in the early architectural design phase. The framework is based on the value for money [VfM] methodology in the life cycle perspective that represents an important decision tool when adopting the optimal system. The overall framework model is based on the evaluation steps presented by: (1) BIM generation, (2) BIM evaluation, and (3) VfM assessment. The LCC analysis, the VfM, and the realization of the chosen option of heating system represent its final step. Since this study is aimed on the evaluation of the most cost-optimal heating system, only the LCC analysis was needed; the model was adapted omitting both the VfM and the realization of the decision (Fig. 3).

- Life-cycle cost assessment - The LCC is defined in The National Institute of Standards and Technology [NIST] Handbook 135 (1995 edition) as the total discounted dollar cost of owning, operating, maintaining, and disposing of a building or a building system over a period of time. Since the life time periods for the LCC calculations in construction are not standardized this study was founded on the references of the NaWoh 4.1.1. certification scheme regulations defining the lifetime for residential buildings of 50 years. ${ }^{34}$ The automatic LCC assessment is carried out with Legep; a tool providing a database for building elements with data on the costs for construction, energy, water, wastewater, cleaning, maintenance, replacement investment, and regular repair observed in their time cycles.

- Inflation and Net Present Value - Increasing prices of energy and raw materials have led to various LCC outcomes. The cost inflation rate of buildings was set at $2 \%$ and the average inflation of energy prices at $4 \%$, both in accordance with the information collected from the Statistical Office of the Republic of Slovenia. ${ }^{35}$ With regard to the calculation of the net present value (Fig. 4), at the time of the investment, all deposits and withdrawals were considered as present value. ${ }^{36}$ The study identified default interest rates of $2 \%$ as the annual inflation, the capital interest of $5.5 \%$ and the actual interest rate of $3.5 \%$.

- Software Tools and Legislation - Far et al. ${ }^{37}$ suggested three BIM uses as integrated into the economic evaluation of LCC: (1) cost estimation with quantity take-off methods, (2) energy consumption analysis, and (3) building maintenance scheduling. ArchiCAD was used to gather and generate data for BIM. Further, the EcoDesigner STAR expansion of ArchiCAD providing automatic BIM to the Building Energy Model (BEM) workflow allows developers to fully utilize the building energy modelling capacities. Currently, there is no LCC tool particularly developed to the Slovenian building sector. ${ }^{38}$ Furthermore, the SIST DIN 276-1:2013, a standard adapted from German DIN 276, is used for the planning of building costs, in particular in the determination and cost breakdown. In addition, the German DIN 18960 is used to determine the price of the building use. ${ }^{39}$ Therefore, for the LCC assessment, the LEGEP was used as an integrated life-cycle analysis tool with database on the description of all building components according to DIN 276 and the cost of their life cycle according to DIN 18960 with NaWoh ${ }^{40}$ certification.

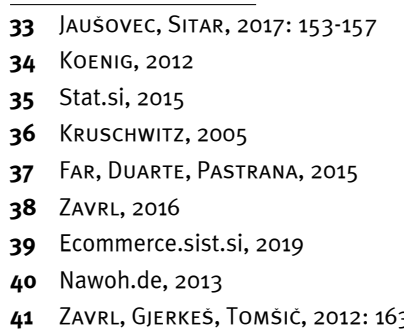


- Case study building, Heating systems and System envelopes selection - The semi-automatic BIM supported LCC assessment was performed on 3 heating systems for 3 alternative prefabricated system envelopes for a case study building of a single-family house. BIM model was created for each option with the same floor space and internal heated volume. The buildings' open glazed elevation is oriented to the south. The case study building is located in Maribor, Slovenia, with average annual temperature of $10.55{ }^{\circ} \mathrm{C}$, minimum temperatures of $-9.67^{\circ} \mathrm{C}$ in January, and the highest temperatures of $+38.17^{\circ} \mathrm{C}$ in July (EcoDesigner). The average annual humidity is $78.82 \%$, and the average solar radiation is $163.80 \mathrm{Wh} / \mathrm{m}^{2}$ and the winds achieve speeds of $2.38 \mathrm{~m} / \mathrm{s}$.

- Case study building - The case study building is performed as a two-story singlefamily house of $7.20 \times 7.20 \times 6.20 \mathrm{~m}[\mathrm{w} / \mathrm{b} / \mathrm{h}]$, $98.77 \mathrm{~m}^{2}$ heated floor area, and $249.90 \mathrm{~m}^{3}$ of total heated volume (Figs. 5-6). Based on the specific scenario for Slovenian attempts to reduce energy consumption, this type and building form was chosen. Namely, in Slovenia, single-family homes represent $75 \%$ of the total housing floor area and $55 \%$ of the entire building sector area. ${ }^{41}$ According to the Annual Report, the domestic average home floor area (brut), excluding basement and/or external storage, is $120 \mathrm{~m}^{2} .^{4^{2}}$

- Heating systems - Recently, in Slovenia the household energy sources are still dominated by wood as $41 \%$, followed by electricity consumption as $26 \%$, natural gas as almost $11 \%$, extra light fuel oil as $9 \%$, district heat as $7 \%$, environmental energy and liquefied petroleum gas, both as 3\% each, and solar energy as $1 \%$ of entire energy sources. Compared to the data of 2016, the largest increase of $6 \%$ is recorded with regard to the use of energy delivered from the environment. ${ }^{33} \mathrm{Ac}$ cordingly, for this study, three heating systems were analysed: (1) Wood pellet stove heating system as widely used for residential houses in recent years because of low prices 44 [EUR/MWh], (2) conventional gas heater with a water tank, and (3) air to water heat pump. The operating profile for chosen heating systems was set as residential, with floor-

\footnotetext{
42 Surveying and Mapping Authority of the Republic of Slovenia, 2015: 25

43 Statistični urad Republike Slovenije, 2018

44 Sistem zagotavljanja kakovosti lesnih pelet, 2016

45 Ministrstvo za okolje in prostor, 2010

46 EcoDesigner STAR User Manual, 2014

47 Lumar, 2015

48 Finance, 2015

49 Solar decathlon Europe, 2012a

50 Solar decathlon Europe technical documentation, 2012 b
}

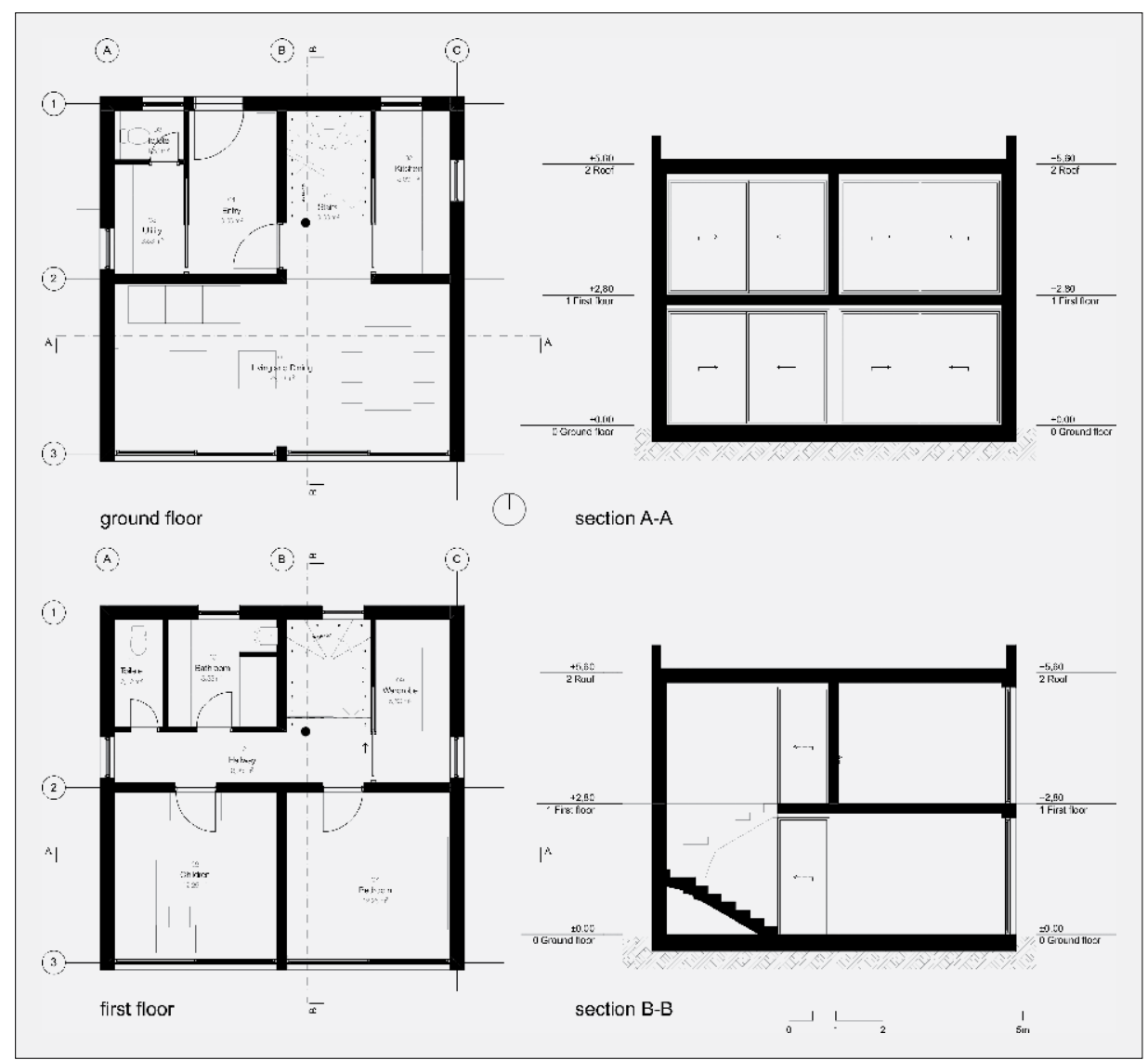

heating and manual window ventilation. As stated in TSG-1-004:2010 45 , the maximum indoor temperature was limited at $26^{\circ} \mathrm{C}$, the minimum temperature at $20^{\circ} \mathrm{C}$. Total usage hours were considered as 8760 hours per year $(365 \times 24$ Hours). The default values set in Archicad reflect the Operation Profile specifications of the DIN 18599 Standard for Energy Efficiency of Buildings. ${ }^{46}$

- Envelopes - For each heating system, 3 alternative prefabricated system envelopes (Fig. 1.) were calculated. The Lumar Primus system envelope [Lumar] was chosen as the reference because in an independent research $^{47}$ the Lumar Primus house was declared the best price performing prefabricated house in Slovenia. The company's bestselling model ${ }^{48}$ with the timber panel system envelope is categorized as a very good low energy house. Furthermore, in regard to the objectives of the study explained above, aiming at the promotion of research and innovation for sustainable architectural design, the prototypes of Solar Decathlon Competition Europe [SDE] 2012 system envelopes ${ }^{49}$, including the evaluation of the selection of categories in the Final SDE jury report ${ }^{50}$, were systematically analysed. There were two system envelopes chosen, (1) Ecolar and (2)
FIG. 5 CASE STUdY BUILDING FLOOR PLANS AND SECTIONS SL. 5. STUdIJA SLUĊAJA - TLOCRTI I PRESJECI

FIG. 6 CASE STUDY BUILDING OF THE TWO-STORY SINGLE-FAMILY HOUSE

SL. 6. STUDIJA SLUĊAJA - IZGRADNJA OBITELJSKE DVOKATNICE

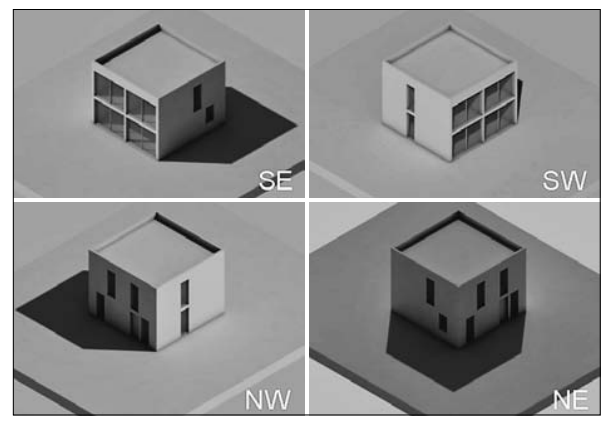




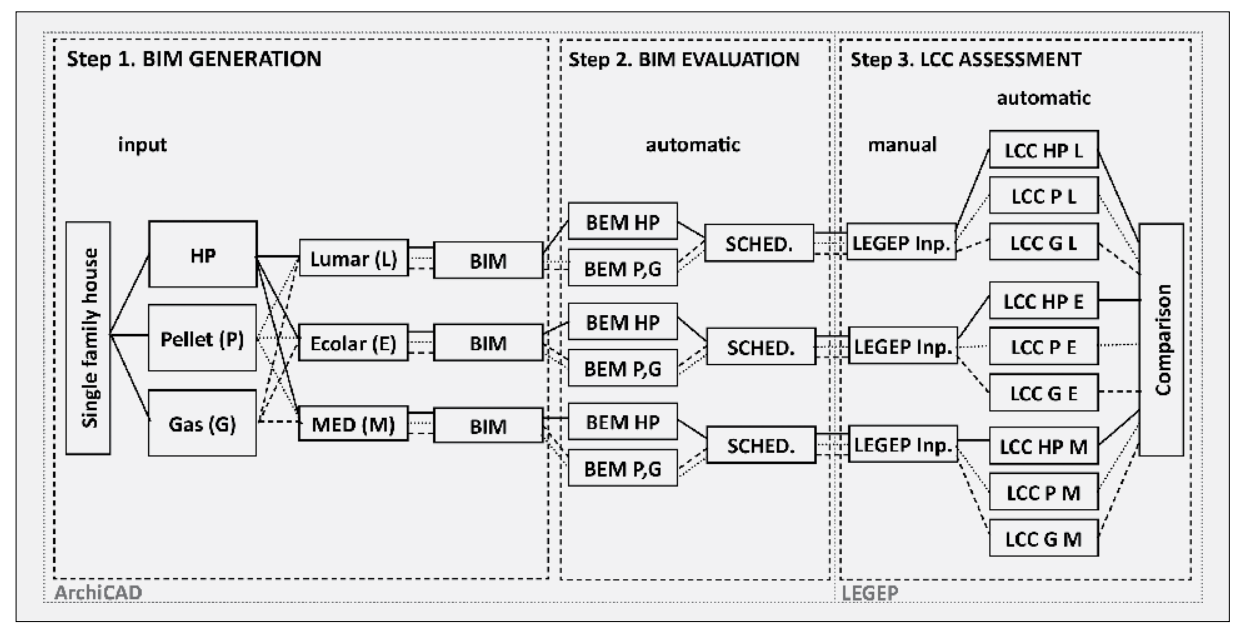

Fig. 7 AN ILLUSTRATion OF the ECEMF USAgE FOR THE COMPARISON OF NINE ALTERNATIVE OPTIONS SL. 7. ILUSTRACIJA KORIŚTENJA ECEMF-A ZA USPOREDBU DEVET ALTERNATIVNIH OPCIJA
MED. The Ecolar system envelope [Ecolar] represents the high-tech system envelope built on specific opaque facade elements with dynamic U-value, while the MED system envelope [MED] represents the low-tech solution adding additional cavity to the standardized prefabricated system panel by thermal mass and smart usage of aluminium pipes and sand.

Furthermore, for this study, the impacts of different thermal capacities were taken into consideration, since the walls and the roof of the single-family house were considered as changing parameters. The foundation slab of $\mathrm{U}=0.15 \mathrm{~W} / \mathrm{m}^{2} \mathrm{~K}$, as recommended by Slovenian regulations on energy efficiency, the first-floor slab and internal walls, as well as the windows and doors, were considered as fixed parameters. For the energy consumption calculation, the $U$-value of timber windows was defined as $0.87 \mathrm{~W} / \mathrm{m}^{2} \mathrm{~K} .{ }^{51}$ All external openings were estimated as shaded with an external shading device of louvers. The illustration of the ECEMF usage for the LCC assessment is presented in Fig. 7 .

\section{RESULTS}

\section{REZULTATI}

The final outcomes of the LCC assessment using the adapted ECEMF on the three heating systems with three alternative envelope systems as shown in Figure 1 are presented in this chapter. They include construction costs $[\mathrm{CC}]$ and operational costs [OpC]. CC were evaluated according to the DIN Standard Cat. 300 and 400 . As presented in Table I, the differences in CC are from the alternations of heating system prices comprising also the installation costs, and from the categorizing material, labour, toll, and processing costs for alternative system envelopes.

The results have proved that Gas heating system [Gas] is characterized by lowest costs, followed by wood pellet burning system [Pellet] and heat pump air to water [HP] systems, the last one assessed as the most expensive solution, due to higher equipment and installation costs $(+46,5 \%)$, presented in Table I. Furthermore, due to the high-tech external wall envelope, the option of HP with Ecolar showed the highest CC. Because of the lowtech based insulation material and smart usage of aluminium pipes, the option of HP with MED represents a good U-value with lower CC, and the Gas with Lumar, as expected, turned out as the option with the lowest CC.

As explained in the introduction and shown in Table III, the OpC added a considerable NPV in the lifetime period of building. These costs are represented by the operation costs [0] including energy and water related costs, the maintenance costs $[M]$, the service and replacement costs [S\&R], and cleaning costs.

According to the results, the $\mathrm{OpC}$ value varies depending on the heating system performance and energy efficiency of external system envelope (Table II). The complete quantity of electricity for lighting and equipment with $609.90 \mathrm{kWh} / \mathrm{a}$ is estimated as the same for all heating systems. The option of HP with Ecolar achieved the lowest energy demands with net heating energy of $31.67 \mathrm{kWh} / \mathrm{m}^{2} \mathrm{a}$. The highest energy demands belonged to the option of Gas or Pellet with Lumar, representing still a good low energy building with a net heating energy value of $36.33 \mathrm{kWh} / \mathrm{m}^{2} \mathrm{a}$ that drops to $32,86 \mathrm{kWh} / \mathrm{m}^{2}$ a with the $\mathrm{HP}$, but considerably increases electricity needs. The option of HP in combination with low-tech MED achieved the second-best Net heating value of $33.54 \mathrm{kWh} / \mathrm{m}^{2} \mathrm{a}$; however, due to smart usage of aluminium pipes lowering the cooling needs resulted in lower equipment energy needs.

The highest $\mathrm{OpC}$ as presented in Table III for the option of Gas with Lumar and the U-value of $0.11 \mathrm{~W} / \mathrm{m}^{2} \mathrm{~K}$ presented the increase of $19 \%$ in 50 years compared to the option of HP with Ecolar that represents the lowest 0 by dynamic $U$-value of $(0.01-0,1)-0.13 \mathrm{~W} / \mathrm{m}^{2} \mathrm{~K}$. Looking only at the heating system options, the HP is characterized by the lowest $O$ costs, while the Pellet produces approximately $10.8 \%$, and the Gas $18.4 \%$ more costs. However, when looking at the altering system envelopes calculated in case of the same heating system, the difference is merely $0.5 \%$. This is important in the context of the CC, in which the difference is $26.2 \%$.

The results of the LCC assessment indicate the efforts to reduce the costs which vary due to different characteristics of the heating systems and envelopes as shown in Table IV. The lowest LCC were presented by the option of Gas with Lumar, characterized by the highest $O$ because of the higher energy consump- 
tion, compensated by the lowest OpC and CC. The highest LCC values were calculated for the option of HP with Ecolar envelope and its higher LCC values of $30.4 \%$, which could be explained as a consequence of much higher $M$ and S\&R costs for the heating system and the system envelope.

Based on the analyses presented in Table IV it can be concluded that $\mathrm{OpC}$ are not only depending on the energy related costs. That is why the functional dependence of the LCC assessment was generalized on the independent $\mathrm{OpC}$, as presented in Table V. The results have shown that $O$ values for the 50 years' period of life time represent between $15.9 \%$ and $28.3 \%$ of $\mathrm{OpC}$ and merely $6.7 \%$ to $11.9 \%$ share of the LCC. Further total operational costs represent between $40.8 \%$ and $43.6 \%$ of total LCC in regard to CC representing the remaining costs.

The comparison of three energy systems used for different envelope systems of the case study building clearly demonstrates that the advanced equipment and materials reduce the 0 including energy consumption, in general. However, due to higher maintenance and service costs during the lifetime, the $\mathrm{OpC}$ are increasing. When observing the outcomes in the users' and owners' perspective, the perception of costs varies heavily. In view of the users, a building with lower 0 is supposed to be more acceptable. In contrast to that, the $M$ and $S \& R$ seem to be more important for the owners. For Slovenian housing market conditions, the findings on the owner's perception is considered as more significant, since according to statistical data, $77 \%$ of residential homes is privately owned..$^{52}$

Based on the outcomes of the study, the relationship between 0 and the LCC was analysed from the users' perspective. The data presented in Table $\mathrm{V}$ showed that the LCC declined only in the case of $\mathrm{OpC}$ for the life time period of 50 years. For users, who would rent a house and pay $\mathrm{O}$ each month, the best system would be the one with the lowest LCC, which was found for the option of HP with Ecolar, and, without the financing of the initial investment, also for the option of $M$ and S\&R. However, the option of Gas with Lumar with lowest LCC achieved the highest 0 (19\% higher) and, therefore, from the users' perspective, it was assessed as the worst case. Nevertheless, when assessing the total LCC, the results show a different outlook. The lowest LCC is found for the option of Gas with Lumar, while the option of HP with Ecolar exceeded by $30.4 \%$ in perspective of 50 years' life time.

51 Ekosklad, 2019

52 Stat.si, 2011
TABLE I CONSTRUCTION COSTS [CC] ACCORDING TO LEGEP TABL. I. TROŠKOVI GRADNJE PREMA LEGEP

\begin{tabular}{|c|c|c|c|c|c|c|c|}
\hline $\begin{array}{l}\text { Heating } \\
\text { system }\end{array}$ & Envelope & $\begin{array}{l}\text { Const.(300) } \\
(€)\end{array}$ & $\begin{array}{l}\text { Techn. Equip. (400) } \\
(€)\end{array}$ & $\begin{array}{l}\text { Heating }(\mathrm{H}) \\
(\boldsymbol{(})\end{array}$ & $\begin{array}{l}\Delta H \\
(\%)\end{array}$ & $\begin{array}{l}\text { CC net }(300 \& 400) \\
(€)\end{array}$ & $\begin{array}{l}\Delta \mathrm{CC} \\
(\%)\end{array}$ \\
\hline \multirow{3}{*}{ Heat pump } & Lumar & $80.211,61$ & $28.552,62$ & $17.863,74$ & 46,5 & $108.764,67$ & 7,6 \\
\hline & Ecolar & $115.963,85$ & $28.523,47$ & $17.863,74$ & 46,5 & $144 \cdot 487,68$ & 30,5 \\
\hline & MED & $88.176,44$ & $28.523,47$ & $17.863,74$ & 46,5 & $116.728,76$ & 13,9 \\
\hline \multirow{3}{*}{ Pellet } & Lumar & $80.211,61$ & $25.811,09$ & $15.151,36$ & 36,9 & $106.052,29$ & 5,3 \\
\hline & Ecolar & $115.963,85$ & $25.811,09$ & $15.151,36$ & 36,9 & $141.775,3$ & 29,1 \\
\hline & MED & $88.176,44$ & $25.811,09$ & $15.151,36$ & 36,9 & $114.016,38$ & 11,9 \\
\hline \multirow{3}{*}{ Gas } & Lumar & $80.211,61$ & $20.213,54$ & $9.553,81$ & 0 & $100.454,74$ & 0 \\
\hline & Ecolar & $115.963,85$ & $20.213,54$ & $9.553,81$ & 0 & $136.177,75$ & 26,2 \\
\hline & MED & $88.176,44$ & $20.213,54$ & $9.553,81$ & 0 & $108.418,83$ & 7,3 \\
\hline
\end{tabular}

TABLE II ENERGY CONSUMPTION RESULTS OF BEM ANALYSIS

TABL. II. REZULTATI POTROŠNJE ENERGIJE PREMA BEM ANALIZI

\begin{tabular}{|c|c|c|c|c|c|c|c|}
\hline $\begin{array}{l}\text { Heating } \\
\text { System }\end{array}$ & \begin{tabular}{|l} 
System \\
Envelope
\end{tabular} & $\begin{array}{l}\text { average U-value } \\
\left(\mathrm{W} / \mathrm{m}^{2} \mathrm{~K}\right)\end{array}$ & $\begin{array}{l}\text { Heating } \\
(\mathrm{kWh} / \mathrm{a})\end{array}$ & $\begin{array}{l}\text { Service hot water } \\
\text { (kWh/a) }\end{array}$ & $\begin{array}{l}\text { Cooling } \\
(\mathrm{kWh} / \mathrm{a})\end{array}$ & $\begin{array}{l}\text { Light. And Equip. } \\
\text { (kWh/a) }\end{array}$ & \begin{tabular}{|l} 
Net heating value \\
$\left(\mathrm{kWh} / \mathrm{m}^{2} \mathrm{a}\right)$
\end{tabular} \\
\hline Pellet, Gas & Lumar Pr. & 0.31 & $3.431,1$ & $2.868,0$ & 355,7 & 609,9 & 36,33 \\
\hline HP & & & $3.103,6$ & $2.765,3$ & 355,8 & $2.366,0$ & 32,86 \\
\hline Pellet, Gas & Ecolar & 0.31 & 3305,3 & 2868,0 & 346,7 & 609,9 & 35,00 \\
\hline HP & & & $2.991,3$ & $2.765,3$ & 346,6 & $2.331,0$ & 31,67 \\
\hline Pellet, Gas & MED & 0.31 & $3 \cdot 381,2$ & $2.868,0$ & 274,3 & 609,9 & 35,80 \\
\hline HP & & & $3.167,6$ & $2.765,3$ & 274,0 & $2.348,0$ & 33,54 \\
\hline
\end{tabular}

Table III Comparison of the Operational Costs [OpC] including: Operation Costs [O], Maintenance Costs [M], AND SERVICE AND REPAIR COSTS [S\&R]

TABL. III. USPOREDBA OPERATIVNIH TROŚKOVA [OPC] KOJI UKLJUČUJU: OPERATIVNE TROŠKOVE [O], TROŚKOVE ODRŻAVANJA [M] I TROŠKOVE SERVISA I POPRAVAKA [S\&R]

\begin{tabular}{|c|c|c|c|c|c|c|c|c|c|}
\hline $\begin{array}{l}\text { Heat. } \\
\text { Sys. }\end{array}$ & Envelope & $\begin{array}{l}0 \\
(€)\end{array}$ & $\begin{array}{l}\Delta 0 \\
\text { (\%) all. }\end{array}$ & $\begin{array}{l}M \\
(€)\end{array}$ & $\begin{array}{l}\Delta M \\
(\%)\end{array}$ & $\begin{array}{l}S \& R \\
(€)\end{array}$ & $\begin{array}{l}\Delta \text { S\&R } \\
\text { (\%) }\end{array}$ & $\begin{array}{l}\text { OpC } \\
(€)\end{array}$ & $\begin{array}{l}\Delta \text { OpC } \\
(\%)\end{array}$ \\
\hline \multirow{3}{*}{ HP } & Lumar & $16.718,39$ & 0,5 & $16.747,35$ & 36,5 & $43.792,02$ & 18,5 & $83.060,28$ & 12,5 \\
\hline & Ecolar & $16.634,80$ & 0 & $17.625,88$ & 39,7 & $58.794,84$ & 39,3 & $103.084,29$ & 29,5 \\
\hline & MED & $16.674,43$ & 0,2 & $16.952,89$ & 37,3 & $50.046,58$ & 28,7 & $89.466,42$ & 18,8 \\
\hline \multirow{3}{*}{ Pellet } & Lumar & $18.775,88$ & 11,4 & $14.758,34$ & 27,9 & $42.534,48$ & 16,1 & $81.861,22$ & 11,3 \\
\hline & Ecolar & $18.653,21$ & 10,8 & $15.626,99$ & 32 & $57.537,3$ & 38 & $104 \cdot 322,31$ & 30,4 \\
\hline & MED & $18.727,2$ & 11,2 & $14.953,86$ & 28,9 & $48.789,04$ & 26,9 & $88.262,62$ & 17,7 \\
\hline \multirow{3}{*}{ Gas } & Lumar & $20.536,77$ & 19 & $10.633,61$ & 0 & $35.679,57$ & 0 & $72.642,47$ & 0 \\
\hline & Ecolar & $20.378,98$ & 18,4 & $11.502,24$ & 7,6 & $50.682,39$ & 29,6 & $93.830,40$ & 22,6 \\
\hline & MED & $20.473,62$ & 18,8 & $10.829,16$ & 1,8 & $41.934,13$ & 14,9 & $79.029,43$ & 8,1 \\
\hline
\end{tabular}

From the owners' perspective, further research on the relationship between the LCC and $M$ was conducted. When looking only at $M$, as the results obtained and compared in Table III, the lowest costs were found again for the option of Gas with Lumar, followed by the option of Gas with MED and with Ecolar.

This data represented that $M$ highly depends on the choice of the heating system option due to higher costs for Pellet and HP.

The results also proved the perception that, when adding $C C$ to $M$, the $L C C$ ranking has not changed, but the difference between $C C$ and $M$ became smaller, since the initial CC difference related to the options of heating system for 50 years' life time was higher than the value difference for $M$. 
TABle IV LCC Assessment of THe three different heAting Systems (GAS, Pellet AND HeAt PUMP) On three DIFFERENT PREFABRICATED ENVELOPES (A LOW ENERGY REFERENCE ENVELOPE, ADVANCED LOW-TECH SOLUTION, AND HIGH-TECH ENVELOPE)

TABL. IV. LCC PROCJENA TRI RAZLICITA SUSTAVA GRIJANJA (PLIN, PELETII DIZALICA TOPLINE) NA TRI RAZLICIITE PREFABRICIRANE OVOJNICE (NISKOENERGETSKA OVOJNICA, NAPREDNO LOW-TECH RJESEENJE I HIGH-TECH OVOJNICA)

\begin{tabular}{|c|c|c|c|c|c|c|c|c|}
\hline $\begin{array}{l}\text { Heat. } \\
\text { Sys. }\end{array}$ & Envelope & \begin{tabular}{|l}
$\mathrm{CC}_{300 \& 400}$ \\
$(\epsilon)$
\end{tabular} & \begin{tabular}{|l|}
$\Delta \mathrm{CCN}$ \\
(\%) all
\end{tabular} & \begin{tabular}{|l} 
OpC \\
$(\epsilon)$
\end{tabular} & \begin{tabular}{|l|}
$\Delta \mathrm{OpC}$ \\
(\%) all
\end{tabular} & $\begin{array}{l}\text { LCC } \\
(\epsilon)\end{array}$ & \begin{tabular}{|l|}
$\Delta \mathrm{LCC}$ \\
(\%) all
\end{tabular} & \begin{tabular}{|l}
$\Delta$ LCC \\
(\%) sys
\end{tabular} \\
\hline \multirow{3}{*}{ HP } & Lumar & $108.764,67$ & 7,6 & $83.060,28$ & 12,5 & $191.824,95$ & 9,8 & 0 \\
\hline & Ecolar & $144 \cdot 487,68$ & 30,5 & $103.084,29$ & 29,5 & $248.809,99$ & 30,4 & 22,9 \\
\hline & MED & $116.728,76$ & 13,9 & $89.466,42$ & 18,8 & $206.195,18$ & 16,1 & 7 \\
\hline \multirow{3}{*}{ Pellet } & Lumar & $106.052,29$ & 5,3 & $81.861,22$ & 11,3 & $187.913,51$ & 7,9 & 0 \\
\hline & Ecolar & $141.775,3$ & 29,1 & $104 \cdot 322,31$ & 30,4 & $244.859,59$ & 29,3 & 23,3 \\
\hline & MED & $114.016,38$ & 11,9 & $88.262,62$ & 17,7 & $202.279,00$ & 14,4 & 7,1 \\
\hline \multirow{3}{*}{ Gas } & Lumar & $100.454,74$ & 0 & $72.642,47$ & 0 & $173.097,21$ & 0 & 0 \\
\hline & Ecolar & $136.177,75$ & 26,2 & $93.830,40$ & 22,6 & $230.008,15$ & 24,7 & 24,7 \\
\hline & MED & $108.418,83$ & 7,3 & $79.029,43$ & 8,1 & $187.448,26$ & 7,7 & 7,7 \\
\hline
\end{tabular}

TABLE V Functional dependence of LCC ON Single VALUe

TABL. V. FUNKCIONALNA OVISNOST LCC O JEDNOJ VRIJEDNOSTI

\begin{tabular}{|c|c|c|c|c|c|c|c|c|c|}
\hline $\begin{array}{l}\text { Heat. } \\
\text { Sys. }\end{array}$ & Envel. & $0(\epsilon)$ & \begin{tabular}{|l}
$M$ \\
$(\epsilon)$
\end{tabular} & \begin{tabular}{|l|} 
S\&R \\
$(\epsilon)$
\end{tabular} & \begin{tabular}{|l}
$\mathrm{OpC}$ \\
$(\epsilon)$
\end{tabular} & $\begin{array}{l}\text { LCC } \\
(\epsilon)\end{array}$ & \begin{tabular}{|l}
$\Delta 0 / 0 \mathrm{pC}$ \\
(\%)
\end{tabular} & \begin{tabular}{|l|}
$\Delta 0 /$ LCC \\
$(\%)$
\end{tabular} & \begin{tabular}{|l}
$\Delta \mathrm{OpC} / \mathrm{LCC}$ \\
$(\%)$
\end{tabular} \\
\hline HP & Lumar & $16.718,39$ & $16.747,35$ & $43.792,02$ & $83.060,28$ & $191.824,95$ & 20,1 & 8,7 & 43,3 \\
\hline Pellet & Lumar & $18.775,88$ & $14.758,34$ & $42.534,48$ & $81.861,22$ & $187.913,51$ & 22,9 & 10 & 43,6 \\
\hline Gas & Lumar & $20.536,77$ & $10.633,61$ & $35.679,57$ & $72.642,47$ & $173.097,21$ & 28,3 & 11,9 & 42 \\
\hline HP & Ecolar & $16.634,80$ & $17.625,88$ & $58.794,84$ & $104 \cdot 322,31$ & $248.809,99$ & 15,9 & 6,7 & 41,9 \\
\hline Pellet & Ecolar & $18.653,21$ & $15.626,99$ & $57.537,3$ & $103.084,29$ & $244.859,59$ & 18,1 & 7,6 & 42,1 \\
\hline Gas & Ecolar & $20.378,98$ & $11.502,24$ & $50.682,39$ & $93.830,40$ & $230.008,15$ & 21,7 & 8,9 & 40,8 \\
\hline HP & MED & $16.674,43$ & $16.952,89$ & $50.046,58$ & $89.466,42$ & $206.195,18$ & 18,6 & 8,1 & 43,4 \\
\hline Pellet & MED & $18.727,2$ & $14.953,86$ & $48.789,04$ & $88.262,62$ & $202.279,00$ & 21,2 & 9,3 & 43,6 \\
\hline Gas & MED & $20.473,62$ & $10.829,16$ & $41.934,13$ & \begin{tabular}{|l|}
$79.029,43$ \\
\end{tabular} & $187.448,26$ & 25,9 & 10,9 & 42,2 \\
\hline
\end{tabular}

GRAPH I LCC ASSESSMENT 0-50 YEARS IN NPV FOR THREE HEATING SYSTEMS ON THREE DIFFERENT ENERGY PERFORMANCE ENVELOPES

GRAF. I. LCC PROCJENA 0-50 GODINA U NETO SADAŠNJOJ VRIJEDNOSTI ZA TRI SUSTAVA GRIJANJA NA TRI RAZLIČITE ENERGETSKI-UČINKOVITE OVOJNICE

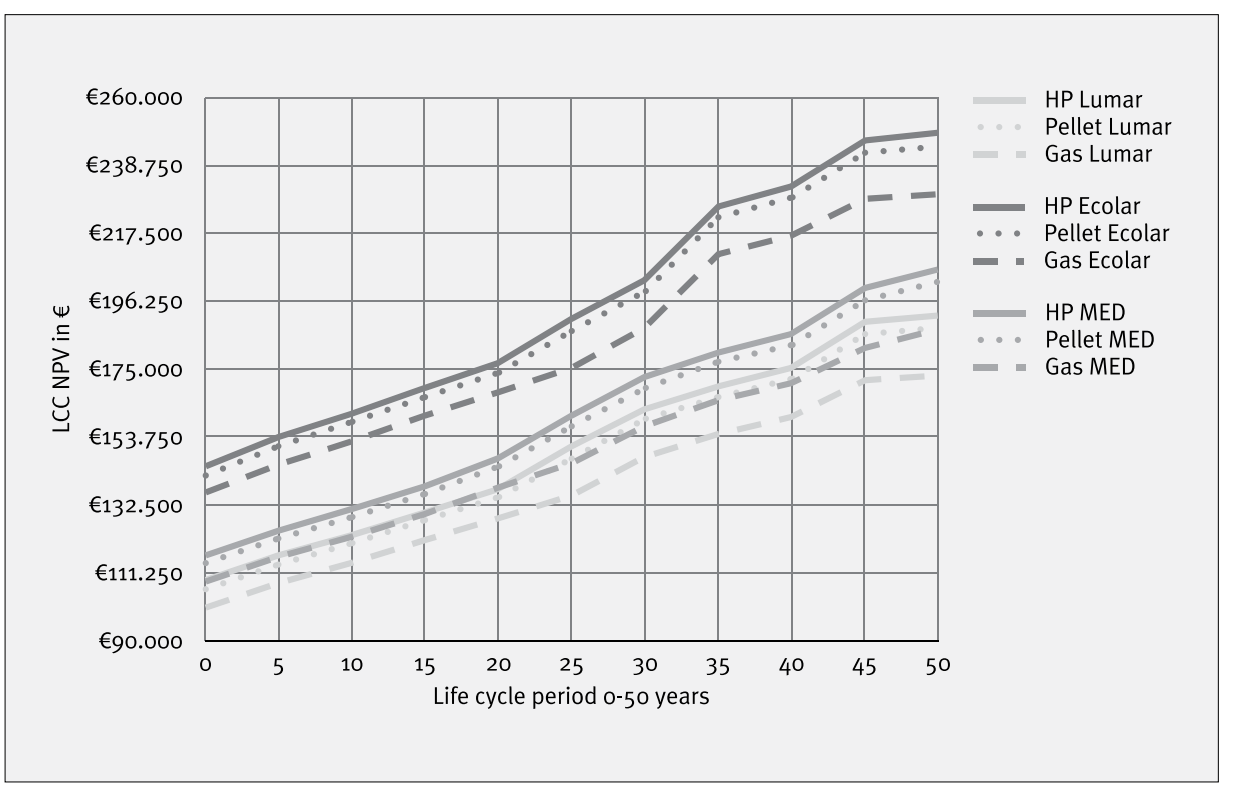

The highest operational costs estimated for S\&R showed approximately three times the value of $M$, and two times value of $O$. According to presented data in Table $\mathrm{V}$, the lowest LCC were again assessed for the option of Gas with Lumar, followed by the option with MED, and of HP with Ecolar, the last one $39.3 \%$ higher due to high S\&R of the HP and the high-tech facade costs. When adding CC to $S \& R$, the $L C C$ ranking remained the same but the value delta margin became smaller. Therefore, it can be concluded that the technologically advanced heating systems and envelopes applied in housing constructions would produce higher $C C, S \& R$ and $M$, as a consequence of higher LCC ranking.

LCC evolution in $\mathbf{5 0}$ years life time - In Graph I the assessment evaluated represents all 9 options of heating systems related to the alternatives of system envelopes for different LCC periods of life time. The calculations have showed the LLC changes throughout the period of 50 years life time observed in the evolution of the 5 -year steps of LCC costs, starting with the initial CC. In the early period of the construction, the value of the option of Gas with Lumar was estimated as the lowest. As a contrast, because of the $26 \%$ higher CC, the option of HP with Ecolar with 30.5\% higher value achieved the highest LCC.

When looking at the comparison of heating systems only in the period after the construction Gas system present the lowest costs, the Pellet heating would be $3.9 \%$ to $5.3 \%$ higher, and the HP options would be $5.8 \%$ to $7.6 \%$ higher. For the first 20 years life time, the LCC values of the Pellet and the HP option would come closer to the Gas heating option, showing in case of Pellet $3.8 \%$ to $4.9 \%$ less, and for HP $5.1 \%$ to $6.6 \%$ less. However, after 25 years life time, because of expected raise of $S \& R$, the LCC differences in ranking would increase again up to $6.3 \%$ for Pellet heating option, and $8.1 \%$ for the HP, with similar cycle results for the next 25 years life time.

The data indicates that none of the alternatives would have a lower LCC than the option of Gas with Lumar. The Pellet option with the same envelope came at closest to the Gas option with $4,9 \%$ higher LCC after 20 years life time. From the owners' and investors' perspective, the option of Gas with Lumar was evaluated as the best. In contrast, from national resources management and users' perspectives, the option of Pellet with Lumar could be suggested as optimal solution, especially for the first 20 years life time.

53 Acknowledgments: The results presented in this paper were obtained as a part of the PhD thesis by Marko Jaušovec with the title Smart Architecture is More Than Just Technology from Faculty of Architecture, Technical University of Graz, Austria, supervised by Prof. Roger Ri ewe and co-supervised by Prof. PhD Metka Sitar. 


\section{DISCUSSION AND CONCLUSIONS}

\section{DISKUSIJA I ZAKLJUČCI}

With regard to various sustainability aspects, the study on BIM supported LCC assessment with the adapted ECEMF model evaluating different heating systems related to advanced energy-efficient prefabricated envelopes provided a range of interesting outcomes. When observing CC and BEM analysis, it is evident that all evaluated options achieved very good U-values (0.07 to $0.14 \mathrm{~W}$ / $\left.\mathrm{m}^{2} \mathrm{~K}\right)$ that are below minimum of Slovenian standards on energy efficiency. The BEM analysis outcomes proved that the best results of the net heating energy were represented by the option of HP with Ecolar, and the worst ones by the simplest option of Gas with Lumar, both values varying up to $12.8 \%$. However, in regard to 0 including the energy related costs, the difference would be $19 \%$. However, the net values of initial CC vary up to $25 \%$ for reasons identified in the option of technologically advanced heating system and envelope design of high-tech. The high increase of initial CC could only be partly repaid by expected lower 0 . When observing only CC, the initial costs of the HP with Ecolar, characterized by dynamic U-value, are higher than CC of the option of Gas with Lumar as expected. Surprisingly, even though 0 as $19 \%$ lower, this option would produce $29.5 \%$ higher $\mathrm{OpC}$. It can be concluded that the options of HP with high-tech envelopes would reduce the energy supply costs, in general, but due to very high $M$ and $S \& R$ the higher costs could not be compensated in 50 years' lifetime. Nevertheless, O represent only $6.7 \%$ to $11.9 \%$ of the total LCC net present value for all 9 heating system options. This is assumed as an important finding in regard to the LCC for its role as a key element in the assessment of environmental sustainability of constructions, enabling the economic evaluation of different heating systems in view of cost benefits when incorporating sustainable options into construction assets. Regardless to higher initial costs for heating systems often perceived as an investment to avoid future
$\mathrm{OpC}$, the results have proved an opposite conclusion.

This study differentiates from other studies on cost-optimal strategies for stakeholders in a range of aspects. In the literature, the majority of studies on BIM based LCC analyses theoretical advantages and/or different evaluation frameworks while more empirical approach is missing. Furthermore, the perceived complexity and time-consuming nature of calculations in case of linear programming led to non-comprehensive BIM-LCC evaluations of economic feasibility. There is no study found on using the BIM-based LCC method for the assessing different heating system options related to alternatives of energy efficient system envelopes, simultaneously. Additionally, this study has used dynamic LCC calculation method, taking into account building cost inflation of $2 \%$, energy price inflation of $4 \%$, real interest rate of $3.5 \%$ and the capital interest rate of $5.5 \%$.

As a conclusion, it is estimated that the main goals of the research were achieved by (i) conducting comprehensive BIM supported LCC assessment of three option on heating systems related to three alternative prefabricated system envelopes, using the original ECEMF, (ii) demonstrating the BIM supported semi-automatic LCC assessment based on a case study building of single-family house, using the Archicad BIM and Legep LCC tools, and (iii) evaluating the most cost-optimal heating system for energy-efficient prefabricated single-family houses based on the three different system envelopes from their life time perspective. As often claimed, technically advanced heating systems related to high-tech system envelopes should provide substantial benefits of energy savings and operation costs in housing sector. However, the comprehensive BIM supported LCC evaluation assessment is indicating a new look on the feasibility providing interesting insights into sustainable architectural design as a challenge for the ongoing research. ${ }^{53}$

[Written in English by the authors; proof-read by URŠKA JODL SKALICKY, univ. dipl. angl.].

\section{BIBLIOGRAPHY LITERATURA}

1. Basbagill, J.; Flager, F.; Lepech, M. (2014), A multi-objective feedback approach for evaluating sequential conceptual building design decisions, "Automation in Construction", 45: 136-150; https://doi.org/10.1016/j.autcon.2014.04.015

2. BRADIC, H.; Verśić, Z. (2018), Modeli transformacije zgrade Osnovne śkole Saburina u Sarajevu kao posljedica zahtjeva energetske ucinkovitosti, “Prostor", 26 (2/56/): 244-257, Zagreb; https://doi.org/10.31522/p.26.2(56).3

3. Civil Engineering Division, Ministry of Transport Public Works \& Water Management (2007), Life cycle costing (LCC) as a contribution to sustainable construction: 3-4, Utrecht

4. Deshrande, A.; Azhar, S.; Amireddy, S. (2014), A Framework for a BIM-based Knowledge Management System, "Procedia Engineering", 85: 113-122; https://doi.org/10.1016/j.proeng. 2014.10.535

5. DU, L.; TANG, W.; LIU, C.; WANG, S.; WANG, T.; Shen, W.; HuANG, M.; Zhou, Y. (2016), Enhancing engineer-procure-construct project performance by partnering in international markets: Perspective from Chinese construction companies, “International Journal of Project Management”, 34 (1): 30-43; https://doi.org/ 10.1016/j.ijproman.2015.09.003

6. EcoDesigner STAR User Manual (2014), GRAPHISOFT, Budapest

7. Far, M.; Duarte, C.; Pastrana, I. (2015), Building Information Electronic Modeling (BIM) Process As An Instrumental Tool For Real Estate Integrated Economic Evaluations, $22^{\text {nd }}$ Annual European Real Estate Society Conference; https://doi.org/10.15396/eres2015_276

8. Ferrara, M.; Fabrizio, E.; Virgone, J.; FilipPi, M. (2016), Energy systems in cost-optimized design of nearly zero-energy buildings, "Automation in Construction", 70: 109-127; https://doi. org/10.1016/j.autcon.2016.06.007

9. Grilo, A.; Jardim-Goncalves, R. (2011), Challenging electronic procurement in the AEC sector: A BIM-based integrated perspective, "Automation in Construction”, 20 (2): 107-114; https: //doi.org/10.1016/j.autcon.2010.09.008

10. Hasan, A.; Vuolle, M.; Sirén, K. (2008), Minimisation of life cycle cost of a detached house using combined simulation and optimisation, “Building and Environment", 43 (12): 2022-2034; https://doi.org/10.1016/j.buildenv.2007.12.003

11. Jaušovec, M.; SitAR, M. (2017), Comparative Evaluation Model for Smart Envelope Systems, in: Energy efficiency, University of Maribor Press: 153-157, Maribor

12. KARAN, E.; IRIZARRY, J. (2015), Extending BIM interoperability to preconstruction operations using geospatial analyses and semantic web services, "Automation in Construction", 53: 1-12; https://doi.org/10.1016/j.autcon.2015.02.012 


\section{SOURCES}

13. Koenig, H. (2012), LEGEP-Handbuch für die Gebäudezertifizierung, Kissing: Weka media

14. KRUSCHWITZ, L. (2005), Investitionsrechnung, R. Oldenbourg, München

15. Lauinger, D.; Caliandro, P.; Van Herle, J.; KUHN, D. (2016), A linear programming approach to the optimization of residential energy systems, “Journal of Energy Storage", 7: 24-37; https://doi.org/10.1016/j.est.2016.04.009

16. LeCKNer, M.; ZMeureanu, R. (2011), Life cycle cost and energy analysis of a Net Zero Energy House with solar combisystem, "Applied Energy", 88 (1): 232-241; https://doi.org/10.1016/j. apenergy.2010.07.031

17. LEE, S.; KIM, S.; NA, Y. (2015), Comparative analysis of energy related performance and construction cost of the external walls in highrise residential buildings, "Energy and Buildings", 99: 67-74; https://doi.org/10.1016/j. enbuild.2015.03.058

18. LoVe, P.; LIU, J.; MAtTheWs, J.; SING, C.; SMITH, J. (2015), Future proofing PPPs: Life-cycle performance measurement and Building Information Modelling, "Automation in Construction", 56: 26-35; https://doi.org/10.1016/j.autcon.2015.04.008

19. Martinopoulos, G.; Papakostas, K.; PapadoPOULOS, A. (2018), A comparative review of heating systems in EU countries, based on efficiency and fuel cost, "Renewable and Sustainable Energy Reviews", 90: 687-699; https://doi. org/10.1016/j.rser.2018.03.060

20. Matic, D.; Calzada, J.; Eric, M.; Babin, M. (2015), Economically feasible energy refurbishment of prefabricated building in Belgrade, Serbia, "Energy and Buildings", 98: 74-81; https:// doi.org/10.1016/j.enbuild.2014.10.041

21. Milan, C.; Bojesen, C.; Nielsen, M. (2012), $A$ cost optimization model for $100 \%$ renewable residential energy supply systems, “Energy”, 48 (1): 118-127; https://doi.org/10.1016/j.energy.2012.05.034

22. Ministrstvo za okolje in prostor (2010), Tehnična smernica TSG-1-004:2010 učinkovita raba energije, Ljubljana

23. Motawa, I.; CARTer, K. (2013), Sustainable BIMbased Evaluation of Buildings, "Procedia - Social and Behavioral Sciences", 74: 419-428; https://doi.org/10.1016/j.sbspro.2013.03.015

24. Nwodo, M.; Anumba, C.; AsAdi, S. (2017), BIMBased Life Cycle Assessment and Costing of Buildings: Current Trends and Opportunities, "Computing in Civil Engineering 2017"; https:// doi.org/10.1061/9780784480847.007

25. Peippo, K.; Lund, P.; Vartiainen, E. (1999), Multivariate optimization of design trade-offs for solar low energy buildings, "Energy and Buildings", 29 (2): 189-205; https://doi.org/10.1016 /So378-7788(98)00055-3

26. Ren, G.; LI, H. (2017), BIM Based Value for Money Assessment in Public-Private Partnership,
"Collaboration in a Data-Rich World": 51-62; https://doi.org/10.1007/978-3-319-65151-4_5

27. SAHA, S. (2011), Cost Effective Thermal Wall System for Residential Housing, "Procedia Engineering”, 14: 1913-1919; https://doi.org/10.1016/j. proeng.2011.07.240

28. Sandvall, A.; Ahlgren, E.; Ekvall, T. (2017), Cost-efficiency of urban heating strategies - Modelling scale effects of low-energy building heat supply, "Energy Strategy Reviews", 18: 212223; https://doi.org/10.1016/j.esr.2017.10.003

29. SANTOS, R.; CostA, A. (2016), BIM in LCA/LCEA Analysis: Comparative analysis of Multi-family House and Single-family, In: Conference: CIB World Building Congress 2016: 1, Tampere

30. Santos, R.; Costa, A.; Silvestre, J.; Pyl, L. (2019), Integration of LCA and LCC analysis within a BIM-based environment, "Automation in Construction", 103: 127-149; https://doi.org/ 10.1016/j.autcon.2019.02.011

31. SHIN, Y.; CHO, K. (2015), BIM Application to Se lect Appropriate Design Alternative with Consideration of LCA and LCCA, "Mathematical Problems in Engineering": 1-14; https://doi.org/ $10.1155 / 2015 / 281640$

32. Statistični urad Republike Slovenije (2018), Količina energije, namenjene koncni rabi, je v letu 2017 znašala 206.000 TJ, Energetska statistika, Slovenija, 2017

33. Surveying and Mapping Authority of the Republic of Slovenia (2015), Annual report on the Slovenian property market for 2014: 25

34. ŠIJANeC ZAVRL, M. (2016), Vseżivljenjsko vrednotenje stroškov pri obnovi stavb, Energija v stavbah: 4

35. UYGUNOĞLU, T.; KEÇEBAŞ, A. (2011), LCC analysis for energy-saving in residential buildings with different types of construction masonry blocks, "Energy and Buildings", 43 (9): 2077-2085; https://doi.org/10.1016/j.enbuild.2011.04.011

36. Wang, W.; Zmeureanu, R.; Rivard, H. (2005), Applying multi-objective genetic algorithms in green building design optimization, "Building and Environment", 40 (11): 1512-1525; https:// doi.org/10.1016/j.buildenv.2004.11.017

37. Xydis, G. (2013), Comparison study between a Renewable Energy Supply System and a supergrid for achieving $100 \%$ from renewable energy sources in Islands, "International Journal of Electrical Power \& Energy Systems”, 46: 198-210; https://doi.org/10.1016/j.ijepes.2012.10.046

38. Yin, B.; LaING, R.; LeON, M.; Mabon, L. (2018), An evaluation of sustainable construction perceptions and practices in Singapore, "Sustainable Cities and Society", 39: 613-620; https:// doi.org/10.1016/j.scs.2018.03.024

39. ZAVRL, M.; GJERKEŠ, H.; TOMŠıč, M. (2012), Integration of Nearly Zero Energy Buildings in Sustainable Networks - a Challenge for Sustainable Building Stock, World engineering forum 2012: 163

\section{INTERNET SOURCES}

\section{INTERNETSKI IZVORI}

1. Ecommerce.sist.si. (2019), Spletna trgovina SIST. [online] Available at: http://ecommerce. sist.si/catalog/ [Accessed 19 Apr. 2019]

2. Ekosklad (2019), Slovenian Environmental Public Fund. [online] Available at: https://www. ekosklad.si/dokumenti/rd/29SUB-OB15/Seznam_okna.xls [Accessed 21 Aug. 2019]

3. Energy - European Commission (2018), Energy performance of buildings - European Commission [online]. Available at: https://ec.europa.eu /energy/en/topics/energy-efficiency/buildings [Accessed 14 Feb. 2019]

4. Finance (2015), Predstavili bodo najbolje prodajano hiso Primus [online]. Available at: http: //www.finance.si/8818940/Predstavili-bodonajbolje-prodajano-hišo-Primus [Accessed 15 May 2015]

5. GLušıč, A. (2019), Pravilnik o učinkoviti rabi energije $v$ stavbah [online] pisrs. Available at: http://www.pisrs.si/Pis.web/pregledPredpisa? id=PRAV 10043 [Accessed 26 Aug. 2019]

6. Graphisoft.com. (2019), About ARCHICAD - $A_{3} D$ architectural BIM software for design \& modeling [online]. Available at: http://www.graphisoft.com/archicad/ [Accessed 6 Jan. 2019]

7. Lumar (2015), Best buy award - Drugic zapored $z$ najboljsim razmerjem med ceno in kakovostjo [online]. Available at: http://www.lumar.si/novica.asp?ID=152 [Accessed 18 Nov. 2015]

8. Nawoh.de. (2013), NaWoh Steckbrief mit Teilindikatoren, ökonomische qualität, Lebenszykluskosten (LCC), Ausgewählte Kosten im Lebenszyklus [online]. Available at: http://www.nawoh. de/uploads/pdf/kriterien/v_3_o/Oekonomische_Qualitaet_V_3_o.pdf[Accessed 26 Oct. 2018]

9. Sistem zagotavljanja kakovosti lesnih pelet (2016), Informacije [online]. Available at: http:// www.s4q.si/info [Accessed 15 Jan. 2016]

10. Solar decathlon Europe (2012a), Solar Decathlon 2012 Documentación Técnica / Solar Decathlon Europe [online]. Available at: http://www. sdeurope.org/downloads/sde2012 [Accessed 20 Oct. 2013]

11. Solar decathlon Europe (2012b), Solar decathlon Europe technical documentation [online]. Available at: http://www.sdeurope.org/downloads/sde2012/ [Accessed 20 Oct. 2013]

12. Stat.si. (2011), Naseljena stanovanja, Slovenija, 1. januar 2011 - zacasni podatki [online]. Available at: http://www.stat.si/StatWeb/glavnanavigacija/podatki $/$ prikazistaronovico? IdNovice $=$ 4420 [Accessed 12 Mar. 2016]

13. Stat.si. (2015), SURS [online]. Available at: http: //www.stat.si/statweb [Accessed 12 Dec. 2015]

\section{Illustration and Table Sources}

\section{IZVORI ILUSTRACIIA I TABLICA}

AUTHORS 


\section{SUMMARY}

SAŽETAK

\section{OPTIMIZACIJA TROŠKOVA U OKVIRU ODRŽIVE ENERGETSKE UČINKOVITOSTI ZGRADA U ARHITEKTONSKOM PROJEKTIRANJU}

Klimatske promjene, kao i velike štete koje uzrokuje izgrađeni okoliš, sve više povecavaju zabrinutost za kvalitetu okoliša. Građevinska industrija s potrošnjom znaçajnih količina sirovina ima snażan utjecaj na održivost društva. U EU samo na građevinski sektor otpada $38 \%$ emisije $\mathrm{CO}_{2}$ i $40 \%$ potrošnje energije. Kako bi smanjila energetsku potrošnju, EU je donijela niz propisa i dokumenata, kao sto je Direktiva o energetskoj učinkovitosti zgrada 2002/91 / EC [EPBD] 2002. godine, usklađenu sa slovenskim Propisima za učinkovito korištenje energije u zgradama 2010., zajedno s Tehničkim smjernicama. Tim se dokumentom propisuju minimalni standardi za projektiranje, izgradnju i odrżavanje održivih zgrada.

U Sloveniji potrošnja energije za grijanje zgrada (od kojih na obiteljske kuce otpada $75 \%$ stambene površine) čini $25 \%$ ukupne potrošnje energije. Usto, važno je istaknuti činjenicu da je gotovo $90 \%$ stambenog fonda u privatnom vlasništvu, što utječe na percepciju investiranja od strane investitora i korisnika. Smjernice za održivu arhitekturu cesto su usredotočene na mjere energetske učinkovitosti kao ključne za odlučivanje sudionika o optimalno isplativom investiranju u zgrade.

Međutim, početni troškovi izgradnje iznose manje od $30 \%$ ukupnih troškova żivotnog ciklusa [LCC] tijekom trajanja zgrade. LCC procjena koristi se kao alat za procjenu različitih arhitektonskih projektnih rješenja, konstrukcija i ovojnica kada se razmatraju troškovi sadašnje vrijednosti u odnosu na ekonomski vijek trajanja svake zgrade, s naglaskom na dugorocnoj financijskoj isplativosti.

U slučaju sistemskih ovojnica mnoge metode procjene LCC uzimaju u obzir samo dijelove operativnih troškova, uključujuci troškove povezane s energijom, ali ne i troškove odrżavanja, servisa i zamjene, te troškove čšscenja i rušenja, koji dodaju značajnu neto-vrijednost tijekom żivotnog ciklusa zgrade. U znanstvenoj literaturi vecina provedenih valorizacija LCC-a u potpunosti isključuje izuzetno vażne parametre, poput troškova servisa i popravaka. K tome, provedene LCC analize bile su ograničene na żivotna razdoblja od 30, 50 ili 80 godina, a nedostaje im metoda procjene u smislu razvoja troškova tijekom specifičnih perioda żivotnog vijeka zgrade.

Kako bi se popunio ovaj jaz $u$ istrażivanju i razumjeli operativni procesi koji ukljucuju i isplativost sustava grijanja, predstavljena studija uvela je sveobuhvatnu metodu procjene optimizacije troškova koja se temelji na informacijskom modeliranju podataka o zgradama [BIM], koja podrżava LCC procjenu. Tip obiteljske kuce široko je rasprostranjen tip stambenih zgrada u Sloveniji pa je stoga uzet kao predmet analize. Postavljen je radni model $s$ podnim grijanjem i ručnom ventilacijom prozora. Nadalje, za studiju su uzeti u obzir utjecaji različitih toplinskih kapaciteta jer se zidovi i krov obiteljske kuce smatraju promjenjivim parametrima.

Na temelju rezultata istrażivanja koji se mogu pronaci u znanstvenoj literaturi, a kojima se identificiraju ograničenja i slabosti s obzirom na LCC procjene, ovaj rad prikazuje sveobuhvatne LCC mogucnosti procjene za tri sustava grijanja, kao što su plin, peleti i toplinska pumpa, u odnosu na tri napredne prefabricirane sistemske ovojnice koje se koriste za obiteljsku kucu kao referentni model, uključujuci visokotehnološki i niskotehnološki tip ovojnice. Studija je provedena prilagođenom verzijom Prosirenog modela komparativne evaluacije [ECEMF], uz korištenje BIM-a kao metode primijenjene na żivotni ciklus objekta u cilju postizanja jednog ili više specifičnih ciljeva. BIM model kreiran je za svaku opciju sustava grijanja u odnosu na alternativne sistemske ovojnice zgrade u studiji slučaja s istom površinom i unutarnjim grijanim volumenom. U skladu s time, studija uključuje pet BIM kategorija: (i) prikupljanje, (ii) generiranje, (iii) analiziranje, (iv) izvještavanje i (v) realizacija.
Kako bi se iskoristio proces automatizirane valorizacije u računalnom okruženju, korišteno je nekoliko programa, kao što su ArchiCAD, BIM softver za arhitektonsko projektiranje i modeliranje za BIM model studije slučaja i BEM evaluacija, u kombinaciji s Legepom, alatom $\mathrm{s}$ bazom podataka za građevinske elemente, uključujuci odgovarajuce troškove izgradnje, energije, vode, otpadnih voda, čišcenja, održavanja, zamjene, redovnih popravaka - promatrane u njihovim vremenskim ciklusima od 50 godina. Razlike u vrijednostima troškova gradnje proizlaze iz razlike u cijenama sustava grijanja, što uključuje i troškove montaże, te iz različitih materijala, rada, transportnih troškova i ugradnje za razlicite sustave ovojnica. Rezultati procjene, $s$ jedne strane, potvrdili su pretpostavku da optimalni vrijednosni parametri visokoučinkovitih zgrada ne ovise samo o tipičnim troškovima koji se odnose na energetski učinkovita projektantska rješenja, dok, s druge strane, operativni troškovi izračunati LCC analizama ne ovise samo o troškovima energije. Nadalje, procjena troškova potrošnje energije tijekom żivotnog ciklusa od 50 godina dokazuje da na troškove grijanja otpada samo između 6,7 i 11,9\% troškova ukupnoga żivotnog ciklusa.

S naglaskom na odrżivoj energetskoj učinkovitosti zgrada, predstavljena studija postigla je glavni cilj za razvijanje metode evaluacije primjenjive kao alat za donošenje odluka, koji bi bio upotrebljiv za optimizaciju troškova stambenih projekata u ranoj etapi arhitektonskog projektiranja. Analize usmjerene na optimiziranje izbora energetski učinkovitih sustava trebale bi se usredotočiti na sveobuhvatnu procjenu koja uključuje sva tehnička rješenja s relevantnim učincima optimizacije troškova. Ipak, rezultati studije predstavljaju novost u pogledu izvedivosti građevinskih konstrukcija i prużaju zanimljiv uvid u održivo arhitektonsko projektiranje kao izazov za istrażivanja.

\section{BIOGRAPHIES}

\section{BIOGRAFIJE}

MARKO JAUŠOVEC received his PhD in architecture from the Faculty of Architecture, Technical University Graz, Austria. He is an architect and researcher specialized in architectural design, BIM, and economic feasibility.

MetKa SITAR, PhD., Assoc. Prof., is an architect, author of scientific papers and editor of monographs on sustainable housing and spatial strategies of urban development with expertise in research at national and international level.
Dr.sc. MARKo JaUŠovec doktorirao je na Arhitektonskom fakultetu Tehničkog sveučilišta u Grazu, Austrija. Kao arhitekt i istrażivać, specijalizirao se za arhitektonsko projektiranje, informacijsko modeliranje građevine i ekonomsku izvedivost.

Dr.sc. METKA SITAR, izvanredna profesorica, arhitektica, autorica znanstvenih radova i urednica monografija o održivom stanovanju i prostornim strategijama urbanog razvoja s iskustvom u istrażivanju na domaćoj i međunarodnoj sceni. 


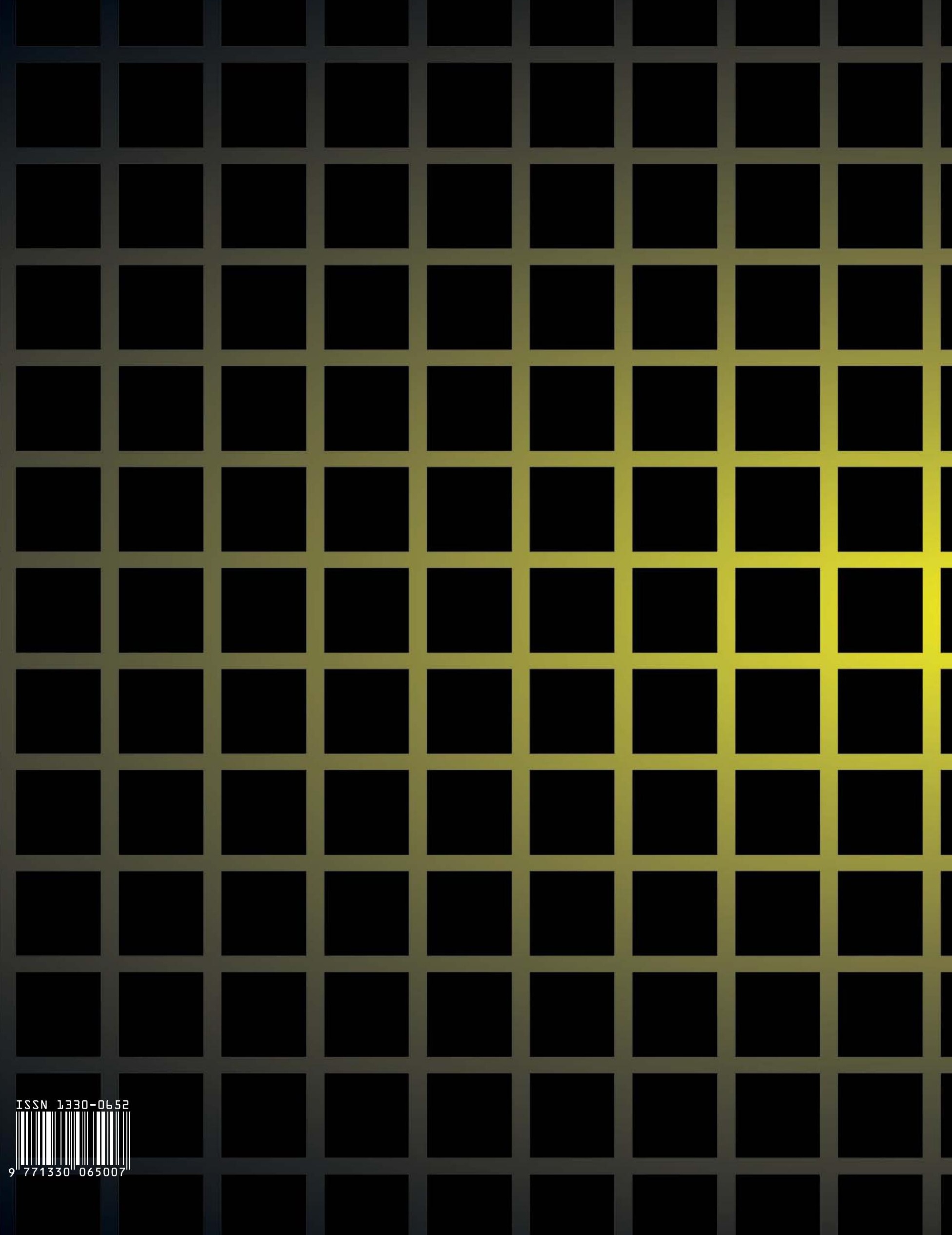

